\title{
EFFECTS OF $\alpha$-CHLOROHYDRIN AND GONADECTOMY ON THE ADENOHYPOPHYSIAL CELLS OF MALE RATS AND GERBILS
}

\author{
V. P. DIXIT, N. K. LOHIYA AND H. G. JAIN \\ Neuroendocrine Section, Department of Zoology, \\ University of Rajasthan, Jaipur 302004, India
}

(Received 8th October 1973)

Alpha-chlorohydrin (3-chlor-1,2 propanediol) possesses antifertility properties when administered to male rats, hamsters, guinea-pigs, rams and monkeys (Ericsson, 1968; Ericsson \& Norland, 1970). The compound is thought to exert its action on the epididymis (Gunn, Gould \& Anderson, 1969; Samojlik \& Chang, 1970). Coppola (1969) and Gunn et al. (1969) suggested that $\alpha$ chlorohydrin might act as a metabolic antagonist to glycerol in phospholipid metabolism and the compound has also been shown to act as an alkylating agent in vitro (Jones, Davies, Edwards \& Jackson, 1969).

The effects of $\alpha$-chlorohydrin on the adenohypophysis have not so far been reported. The purpose of the present investigation was to compare the cytological changes occurring in the gonadotrophic cells of the anterior lobe of the pituitary in male rats and gerbils after the administration of $\alpha$-chlorohydrin, with those changes following bilateral gonadectomy.

The $\alpha$-chlorohydrin (sp. gr. 1.326) was supplied by Upjohn Company, Kalamazoo, Michigan, in $0.25 \%$ aqueous $(1.3 \mathrm{~g} / \mathrm{ml})$ methylcellulose. A working solution was prepared by diluting the stock solution with distilled water.

Thirty adult male gerbils (Meriones hurrianae) and thirty male rats were allotted to six groups of ten each. The drug was given orally, the gerbils receiving $20 \mathrm{mg} / \mathrm{kg} /$ day for 50 days and the rats, $25 \mathrm{mg} / \mathrm{kg} /$ day for 24 days. An equal number of controls received distilled water. The animals were killed $24 \mathrm{hr}$ after administration of the final dose and various organs were removed, weighed and fixed. Pituitaries were fixed in Halmi's Susa (Susa: saturated picric acid, $9: 1 \mathrm{v} / \mathrm{v}$ ), processed, sectioned at $5 \mu \mathrm{m}$ and stained with periodic acid Schiff (PAS)-orange G-methyl blue, and Cleveland-Wolfe trichromic stains. Differential cell counts were made in the sections stained with GlevelandWolfe trichromic stain.

The investigations revealed that administration of $\alpha$-chlorohydrin to adult male gerbils and rats was associated with a decrease in the weights of the testes and accessory sex glands (Table 1) and inhibited spermatogenesis (unpublished observations). A significant decrease in thymus weight was also noted (gerbil, $36.6 \%$; rat, $38.5 \%$ ), but there was no significant influence on the adrenal and thyroid weights.

Although the general structure of the normal rat pituitaries is well known, that of the gerbil is less familiar. The gland consists of three distinct parts: pars 
anterior, pars intermedia and pars nervosa. The median eminence forms the main component of the stalk with the pars tuberalis. In the pars anterior, six chromophil cell types: erythrosinophil or lactotroph (LTH-cell); orangeophil or somatotroph (STH-cell); FSH-gonadotroph; LH-gonadotroph; thyrotroph and ACTH cells, have been distinguished (Kaul \& Ramaswami, 1973).

In rat and gerbil, the largest number of PAS-positive cells were found at the periphery of the gland, particularly in the region adjacent to the pars intermedia. The cytoplasm of these cells stained deeply with Cleveland-Wolfe aniline blue. The nuclei showed a distinct chromatin framework with a well-developed Golgi body. The PAS-Orange G-methyl blue staining technique showed that PAS-purple cells were more numerous than PAS-red cells. The former have been identified as delta-basiphils (FSH-cells) in both rats (Lakshman \& Isaac, 1973) and gerbils (Kaul \& Ramaswami, 1973). Treatment with $\alpha$-chlorohydrin brought about remarkable changes in the delta-basiphils. The cell cytoplasm showed fine granulation and vacuolization. Castration vacuoles appeared in many delta-basiphils of the anterior lobe.

Table 2. Pituitary cytology of the intact, castrated and $\alpha$-chlorohydrin-treated gerbils

\begin{tabular}{c|c|c|c|c|c}
\hline \multirow{3}{*}{ Group } & Treatment & $\begin{array}{c}\text { Basiphils/ } \\
\text { median } \\
\text { sagittal } \\
\text { section }\end{array}$ & $\begin{array}{c}\text { Acidophils/ } \\
\text { median } \\
\text { sagittal } \\
\text { section }\end{array}$ & $\begin{array}{c}\text { Chromophobes/ } \\
\text { median } \\
\text { sagittal } \\
\text { section }\end{array}$ & $\begin{array}{c}\text { Total no. } \\
\text { of } \\
\text { cells counted }\end{array}$ \\
\hline 1 & Control & $\begin{array}{c}444 \pm 56 * \\
(15 \cdot 5 \pm 1 \cdot 5 \%)\end{array}$ & $\begin{array}{c}1022 \pm 143 \\
(35 \cdot 7 \pm 2 \cdot 3 \%)\end{array}$ & $\begin{array}{c}1401 \pm 117 \\
(48 \cdot 8 \pm 2 \cdot 7 \%)\end{array}$ & 14335 \\
2 & Castration & $930 \pm 67$ & $815 \pm 80$ & $1540 \pm 89$ & 16425 \\
3 & $(30$ days) & $(28 \cdot 6 \pm 0 \cdot 5 \%)$ & $(24 \cdot 8 \pm 3 \cdot 9 \%)$ & $(46 \cdot 6 \pm 1 \cdot 8 \%)$ & 17205 \\
& $\alpha-$ Chlorohydrin & $741 \pm 44$ & $964 \pm 29$ & $1736 \pm 59$ \\
& $(75$ mg orally) & $(21 \cdot 5 \pm 2 \cdot 6 \%)$ & $(28 \cdot 0 \pm 5 \cdot 2 \%)$ & $(50 \cdot 5 \pm 5 \cdot 7 \%)$ & 17205 \\
\hline
\end{tabular}

* Mean \pm S.E.

It is well known that gonadectomy leads to hypertrophy and hyperplasia of the castration cells (Mietkiewski, Malendowicz \& Lukaszyk, 1969). On the 30 th postoperative day, a large number of castration cells were noticed in the gerbils and rats. These cells had characteristic ring-like vacuoles of various sizes and the Golgi bodies were hypertrophied.

In the pars anterior of the gerbil pituitary, there were few basiphils, many acidophils and a considerable number of chromophobes (Table 2). Treatment with $\alpha$-chlorohydrin brought about an increase in the percentage of basiphils from $15.5 \%$ (Group 1; Table 2) to $21.5 \%$ (Group 3). The percentage of acidophils dropped significantly $(P<0.01)$, but the percentage of chromophobes in Groups 1 and 3 remained unchanged (Table 2).

In castrated gerbils, the basiphilic cell percentage increased very greatly $(28.6 \%)$.

The results of the present investigation revealed that $\alpha$-chlorohydrin exerts its effects on the androgen-dependent structures such as seminal vesicles, ventral prostate, epididymides and perineal complex (including the levator ani muscles, 
penis and bulb of the penis). These effects are reversible followed by a period of 40 days recovery in rats and gerbils (Table 1 ).

The compound brings about transient changes resembling those of castration in the anterior lobe of the pituitary of male rats and gerbils. In the treated gerbil, there was a marked decrease in the number of acidophils (Table 2), which have been shown to be the source of growth hormone and of prolactin in the adenohypophysis (Purves, 1961). A rise in the activity of the gonadotrophic cells following $\alpha$-chlorohydrin administration is quite conclusive in the increased basiphilic cell percentage $(15.5 \%$ to $21.5 \%)$.

We are grateful to Professor P. N. Srivastava for providing facilities. The investigation was supported by University Grants Commission, New Delhi, India.

\section{REFERENCES}

Coppola, J. A. (1969) An extragonadal male antifertility agent. Life Sci. 8, 43.

ERICsson, R. J. (1968) U-5897: a post-testicular antifertility drug. F. Reprod. Fert. 18, 156.

ERICsson, R. J. \& NorLAND, J. F. (1970) Androgen involvement with male antifertility compound $\alpha$-chlorohydrin. Excerpta Med., Int. Congr. Ser. 210, 174.

Gunn, S. A., Gound, T. G. \& Anderson, W. A. D. (1969) Possible mechanism of post-testicular antifertility action of 3-chloro-1,2-propanediol. Proc. Soc. exp. Biol. Med. 132, 656.

Jones, A. R., Davies, P., Edwards, K. \& Jackson, H. (1969) Antifertility effects and metabolism of $\alpha$ and epi-chlorohydrins in the rat. Nature, Lond. 224, 83.

Kayl, D. K. \& Ramaswami, L. S. (1973) Cytology of the pituitary gland of the Indian desert gerbil (Meriones hurrianae Jerdon). Acta anat. (In press).

Lakshman, A. B. \& IsaAc, P. (1973) Effects of cyproterone acetate on the adenohypophysial cells of male rats. F. Reprod. Fert. 32, 141.

Mietkiewski, K., Malendowicz, L. \& Lukaszyk, A. (1969) Cytological and cytochemical comparative study on the effect of cyproterone (anti-androgen) and gonadectomy on the gonadotrophic cells of the hypophysis in male rats. Acta endocr., Copenh. 61, 293.

Purves, H. D. (1961) Morphology of the hypophysis related to its function. In Sex and Internal Secretions, 3rd edn, p. 161. Ed. W. C. Young. Williams \& Wilkins, Baltimore.

Samojtik, E. \& Ghang, M. C. (1970) Antifertility activity of 3-chloro-1,2-propanediol (U-5897) on male rats. Biol. Reprod. 2, 299. 